\title{
OD RZECZYPOSPOLITEJ SZLACHECKIEJ DO IV RP. KRÓTKI PRZEGLĄD POLSKIEJ MITOLOGII ZAŁOŻYCIELSKIEJ
}

\author{
FROM THE NOBLE REPUBLIC OF POLAND \\ TO THE FOURTH REPUBLIC: \\ A SHORT REVIEW OF POLISH FOUNDING MYTHS
}

\begin{abstract}
There is one type of political myths returning especially often in the Polish political space. This type of myth, founding myth, gains a lot of followers especially during social crises. The main aim of this article is to remind the most popular Polish founding myths together with their historical context. Moreover, a comparison of the past political myths function with their latest variation, the so-called "Fourth Republic of Poland" founding myths, was described. In the summary section, a special attention is devoted to the danger related with using the founding myths for particular motivated political interests.
\end{abstract}

Key words: political myths; Polish founding myths; Fourth Republic of Poland

\section{Streszczenie}

Istnieje jeden typ mitów politycznych szczególnie często powracający w różnorodnej konfiguracji w polskiej przestrzeni politycznej. Mowa tutaj o micie założycielskim, który, co zresztą symptomatyczne, zyskuje sobie sympatyków i wyznawców w chwilach mniej lub bardziej głębokich kryzysów społecznych. Niniejszy artykut ma na celu z jednej strony przypomnienie najpopularniejszych polskich mitów założycielskich wraz
MICHAL FUTYRA Wyższa Szkoła Europejska im. ks. Józefa Tischnera, Kraków E-mail: michalfutyra@interia.pl

CITATION: Futyra, M. (2017) Od Rzeczypospolitej szlacheckiej do IV RP Krótki przegląd polskiej mitologii założycielskiej. Sprawy Narodowościowe. Seria nowa, 2017(49). https://doi.org/10.11649/sn.1324

This work was supported by the author's own resources. No competing interests have been declared.

This is an Open Access article distributed under the terms of the Creative Commons Attribution 3.0 PL License (creativecommons.org/licenses/by/3.0/pl/), which permits redistribution, commercial and non-commercial, provided that the article is properly cited. (C) The Author(s) 2017

Publisher: Institute of Slavic Studies, Polish Academy of Sciences 
z ich historycznym kontekstem. Z drugiej zaś dokonanie porównania funkcji minionych politycznych mitów z ich najnowszą odsłoną w postaci mitów założycielskich tzw. IV Rzeczypospolitej. W podsumowaniu artykułu zwracam również uwagę na niebezpieczeństwo związane z wykorzystywaniem mitów założycielskich przez partykularnie motywowane interesy polityczne.

Stowa kluczowe: mity polityczne; polskie mity założycielskie; IV Rzeczpospolita

\section{MIT ZALOŻYCIELSKI W POLITYCE}

P omimo racjonalizacji życia społecznego myślenie mityczne pozostaje $w$ dalszym ciągu aktualne, a w sposób szczególny dotyczy aktywności politycznej. System polityczny chociaż zachowuje pozorną logiczność, odwołuje się przede wszystkim do zbiorowych emocji. Dlatego tworzy własną mitologię nadającą kształt i sens rzeczywistości (Solak \& Churska-Nowak, 2011, s. 233). Z tego punktu widzenia mit polityczny należy rozumieć jako formę świadomości społecznej, wpływającą na rozumienie oraz sposób wspólnotowego przeżywania wydarzeń politycznych. Tym samym mity wykorzystywane są często w przestrzeni politycznej jako mechanizm zaspokajania ogólnospołecznych pragnień, zbiorowych wyobrażeń oraz wspólnotowych dążeń (Cassirer, 1971, ss. 76-106). Ich wyrazem pozostaje instytucja nowo powstającego państwa, obudowywana mitycznymi wyobrażeniami. Mity założycielskie mają szczególne znaczenie dla tych narodów, które tworzą od podstaw zbiorową pamięć społeczeństwa oraz formują fundamenty swoich instytucji (Siewierska-Chmaj, 2009, s. 32). Mity takie spełniają funkcję poznawczą, oswajają z rzeczywistością, oferują poczucie kolektywnej przynależności (Churska, 2005, s. 66). Aby uzasadnić powstanie, a w przypadku niektórych państw, odrodzenie państwowości zarówno w przeszłości, jak i dzisiaj sięga się po mitologię fundacyjną. Stanowi to alternatywę dla nieprzychylnej historii, trudnych doświadczeń społecznych, czy w końcu instrument nadający przeszłości, a więc pochodzeniu państwa, chwalebny kształt. I tak mit założycielski i mit początku, chociaż nie sposób postawić między nimi znaku równości, opowiadają o rozpoczęciu panowania władzy politycznej (Sielski, 2013, s. 15). Pierwszy z reguły wyjaśniał powody, dla których naród wziął we władanie określone ziemie, drugi zaś - dostarczał dowodów na mityczną identyfikację członków narodu ze sobą nawzajem oraz z instytucją państwa. Historyczna złożoność polskich doświadczeń wytworzyła specyficzny rodzaj mitologii założycielskiej, w której mity fundacyjne przeplatały się z mitami początku. Wynikało to z przerywanego długimi okresami wojen oraz zaborów poczucia braku rzeczywistej państwowości. Duża liczba i siła oddziaływania pojawiających się na przestrzeni dziejów polskich mitów założycielskich nie jest czymś wyjątkowym. Zastanawiające natomiast pozostaje ich cykliczne powracanie.

\section{SARMACI RZECZYPOSPOLITEJ OBOJGA NARODÓW}

Próba analizy mitów założycielskich i początku sprzed okresu powstania II Rzeczypospolitej napotyka oczywistą trudność. Mówiąc o mitach tego typu, mówimy o bycie, do którego owe mity muszą się odnosić, a czego oczywistym punktem odniesienia pozostaje instytucja państwa. Innymi słowy, istnieć musi przestrzeń polityczna, której mity będą dotyczyć. Jeśli założymy, iż taką płaszczyzną jest państwo narodowe, to nie sposób zba- 
dać mitów założycielskich z czasów sprzed utworzenia młodego państwa polskiego po 1918 roku. Z drugiej jednak strony nie można zaprzeczyć, iż odzyskanie niepodległości było jedynie, przynajmniej w oczach Polaków, odzyskaniem należnej suwerenności i samostanowienia po ponad stu latach obcej dominacji. Problem zasadniczy w badaniach mitów założycielskich czasów przedrozbiorowych sprowadzić należy do kwestii tego, jak wyjaśnimy istotę państwa oraz tego, kto owo państwo reprezentowat. Rozwiązanie pierwszego dylematu jest dość proste. Uznajmy, iż państwo w okresie I Rzeczypospolitej utożsamić można w mniejszym stopniu z terytorium, które obejmowało, a w większym -- ze wspólnotą języków, tradycji, kultury, panującej dynastii oraz religii (Biernat, 1989, s. 171). Z kolei odpowiedź na pytanie, która zbiorowość bądź warstwa społeczna rościła sobie prawo do przedstawicielstwa ogółu mieszkańców państwa, jest już znacznie bardziej skomplikowana. W zasadzie podwójnie skomplikowana. Pierwsza trudność wiąże się z tym, co współcześnie określa się mianem narodu. Idea narodu we współczesnej odsłonie to wynik społecznych i gospodarczych przemian XIX wieku, mających niewiele wspólnego z rozumieniem wspólnoty narodowej chociażby z wieku XVIII (Hobsbawm, 2010, ss. 25-53). Świadomość narodowa, czy szeroko rozumiane poczucie tożsamości narodowej w czasach Rzeczypospolitej Obojga Narodów dotyczyło stosunkowo nielicznej warstwy społecznej: szlachty i magnaterii (i to nie jedynie etnicznie polskiej). Podwójne oblicze trudności wiąże się również z wyjątkowym charakterem instytucji ówczesnego państwa. Unijny charakter Rzeczypospolitej komplikował kwestie przynależności narodowej, czy uproszczając, komu należało dochować wierności - panu na włościach, stanowi, dynastii panującej, a być może wspólnocie pochodzenia (Koronie Królestwa Polskiego lub Wielkiemu Księstwu Litewskiemu).

Szlachecka świadomość narodowa przed rozbiorami rozumiana być powinna jako dbatość o interesy - własne, rodziny i krewnych, stanu, a ostatecznie królestwa (Łastawski, 2007, ss. 285-286). I dokładnie w takiej właśnie kolejności. Poczucie bycia szlachcicem wiązało się z dbaniem również o zachowanie szeregu przywilejów wymuszanych na panującym władcy, a które ostatecznie walnie przyczyniły się do upadku potęgi Rzeczypospolitej. Najwymowniejszym określeniem ówczesnej sytuacji w Polsce jest zdanie krążące po europejskich salonach: „Polska jest otchłanią dla królów, niebem dla szlachty, czyśćcem dla duchowieństwa, piekłem dla chłopów, rajem dla Żydów, kopalnią złota dla kupców" (Bartnik, 1990, s. 86). Szlacheckość dawała jej posiadaczowi -- chociażby nawet była to szlacheckość wyłącznie z nazwy, zagrodowa lub brukowa, a jedynym jej atrybutem pozostawało rodowe nazwisko i herb -- poczucie przynależności do obywatelskiej "grupy" interesu.

W tym kontekście na uwagę zasługuje mit sarmacki, który legł u podstaw przekonania o wyjątkowości "narodu szlacheckiego" oraz jego uprzywilejowanego statusu. Na przestrzeni dziejów mit sarmacki ulegał przeobrażeniu, co zresztą typowe dla każdego mitu, jednakże mityczna zasada pozostawała w zasadniczym stopniu niezmienna. Według niej szlachta początkowo polska, a później również litewska oraz ruska wywodziły swoje pochodzenie od Sarmatów. Ci z kolei mieli być potomkami nomadycznych plemion irańskich, które znane były w starożytności jako Jazygowie, Roksolanowie czy Alanowie. Według mitu Sarmaci uchodzili za wyjątkowo waleczne oraz odważne plemię, które nigdy nie uległo w walce rzymskim legionom. Mityczne przekonania stały w jawnej sprzeczności

\section{-....}

Symptomatyczne jest to, iż w zacytowanym porzekadle brakuje wzmianki o mieszczaństwie, którego siła, wpływy oraz znaczenie, mimo powolnego wzrostu, były przez większą część istnienia I Rzeczypospolitej marginalizowane. 
z późniejszymi historycznymi badaniami, według których ludy słowiańskie nie są w żaden sposób spokrewnione z Sarmatami. Co więcej, nie byli Sarmaci niepokonani, gdyż wskutek wojen markomańskich z II wieku n.e. w bezpośrednich zmaganiach z legionami ponieśli klęskę i zostali rozbici na niewiele znaczące klany (Olędzki, 2011, ss. 162-166). Jednakże nie historyczna prawda jest tutaj istotna. Pomimo tego, że mit sarmacki pozostaje historią fałszywej identyfikacji, to z sukcesem spełniał swą funkcję w ustanawianiu świadomości narodowej szlachty oraz rozwoju ideologii monarchii Jagiellońskiej (Zabłocki, 1975, ss. 124-125).

W początkowej fazie funkcja tego mitu wydaje się dość oczywista: pochodzenie od wspólnych antycznych przodków oraz sięgająca starożytności historia jednoczących się plemion polskich, mająca uzasadniać obecność na terytoriach dawnej Polski. Z tej perspektywy mit sarmacki podobny jest do kultu świętego Stanisława z XIV i XV wieku jako symbolu zjednoczenia państwa po rozbiciu dzielnicowym. Mit sarmacki, oprócz oczywistej funkcji wewnętrznej, spełniał również istotną rolę zewnętrzną. Wszelkie obce roszczenia do zwierzchnictwa, chociażby tylko symbolicznego (jak papieskie) nad polskimi ziemiami miały ustępować starożytnemu rodowodowi Polaków jako jedynych prawowitych i niepodzielnych władców zamieszkiwanych ziem. Z duchem następujących zmian politycznych po unii lubelskiej, mit sarmacki posłużył zmianie genezy powstania narodu polskiego. Po narodzinach Rzeczypospolitej Obojga Narodów oraz w wyniku separatystycznych tendencji Litwinów na pierwszy plan wysunęła się potrzeba unifikacji królestwa pod przewodnictwem panującego monarchy. W epoce zygmuntowskiej mit sarmacki przestał podkreślać wyłączne pochodzenie Polaków od sarmackich przodków. Mit zaczyna stopniowo rozciągać się na wszystkie ludy zjednoczonej, wielonarodowej Rzeczypospolitej. Zmiana następuje również w jego treści. O ile wcześniej podkreślano waleczność oraz plemienną wspólnotowość odziedziczoną po barbarzyńskich przodkach, o tyle u schyłku wieków średnich wagi nabiera jakoby podarowana w spadku republikańska tradycja Rzymu. Dzięki temu łatwiejsze staje się wyjaśnianie potrzeby współdziałania w ramach unii polsko-litewskiej. Osobliwym zatem paradoksem pozostaje fakt wspótistnienia w micie sprzecznych poglądów wyrażanych w idei barbarzyńskiego pochodzenia, przy jednoczesnym myśleniu zasadzającym się na kulturze Rzymu, który zażarcie przecież zwalczał Sarmatów (Zabłocki, 1975, s. 129).

W zgodzie z mitologią założycielską Rzeczypospolitej Obojga Narodów lokuje się również mit przedmurza chrześcijaństwa, który stanowił uzupełnienie idei sarmatyzmu. Jeśli uznamy za główne cechy sarmatyzmu daleko posuniętą wolność szlachecką graniczącą z anarchią i swoistą megalomanię ludu herbowego, to mit przedmurza wpisuje się w kolejną jego cechę, jaką było połączenie dewocyjnego religijnego fanatyzmu z przekonaniem o kulturowo-religijnej misji szlachty Rzeczypospolitej (Łastawski, 2007, s. 285).

Mit Antemurale Christianitatis zakorzeniony był silnie w świadomości narodowej szlachty, dla której obrona tradycji i wartości polskich pozostawała tożsama z ochroną wiary katolickiej przed zagrożeniem ze Wschodu. Sedno mitu wyrażało się we wspomnianej powyżej dziejowej misji I Rzeczypospolitej, która przejawiać się miała w strzeżeniu wschodnich rubieży katolickiej Europy przed napływem innowierców. Przedmurze kryło zatem za sobą podwójne znaczenie: wyznaniowe (jako bariera przed islamem) oraz cywilizacyjno-polityczne (jako zapora europejskiej cywilizacji przed azjatyckim barbarzyństwem). Od XV wieku aż do bitwy pod Wiedniem mit przedmurza, oprócz wzmacniania ducha narodowego, służył też polskiej racji stanu jako argument w pozyskiwaniu funduszy oraz positków zza granicy w walce z nieprzyjaciółmi (Tazbir, 1987, ss. 141-142, cyt. za: Łastawski, 2007, s. 298). 
Na uwage zasługuje fakt, iż funkcję wroga w tym micie odgrywały różne narody i to niekoniecznie przybywające ze Wschodu. O ile początkowo zagrożenie utożsamiane było jednoznacznie z tureckim Imperium Osmańskim oraz Moskwą, o tyle z czasem była to również protestancka, ulokowana na północy Szwecja, czy wcześniej. katolicki skądinąd, Zakon Krzyżacki. Zakwalifikowanie mitu przedmurza w krąg mitologii założycielskiej wydaje się zrozumiałe. Wyjątkowa rola i zaszczytny obowiązek powierzony przez Boga, los lub historię przypadać mógł jedynie powołanemu do tego, nadzwyczajnemu narodowi. Czuwanie na straży chrześcijańskiej Europy to automatyczny prestiż międzynarodowy, który skutecznie przesłaniał właściwe miejsce i pozycję Rzeczypospolitej na mapie kontynentu (Biernat, 1989, s. 216). Odgrywając mityczną rolę. naród polski miał zatem na uwadze dobro szersze aniżeli tylko własne. Tym samym za wypełnianie tej niełatwej misji należeć się powinna Polsce rekompensata od Boga (za walkę z innowiercami), od Europy (za ochronę) oraz od historii (za zapisywanie się w niej chwalebnymi czynami). Rzecz jasna irracjonalne wnioski oraz wyobrażenia związane z mitem przedmurza przesłaniały autentyczny obraz rzeczywistości, w której Rzeczpospolita chyliła się coraz wyraźniej ku niebytowi politycznemu. I tak gotowość do złożenia życia na ołtarzu wiary oraz poświęcenie się w imię religii skrywały militarną bezsilność państwa. Kontrast pomiędzy mityczną wizją patriotyzmu krwi a brakiem chęci zasilania budżetu państwa podatkami, i w konsekwencji pozbywania Rzeczypospolitej skutecznej armii kontraktowej, zakrawa przy tym wyraźnie na ironię. Co ciekawe, w schyłkowym okresie I Rzeczypospolitej mit przedmurza zaczynał działać w odwrotną stronę. W świadomości narodowej zrodziło się przekonanie, iż wielowiekowa, aktywna rola Polski jako obrońcy cywilizacji Zachodu zostanie wkrótce wynagrodzona. Im bardziej realne stawało się zagrożenie rozbiorami, tym przekonanie o ochronie przez Europę, Boga i historię wzrastało. Rzeczywistość okazała się jednak brutalna. Tym bardziej że niespełna sto lat wcześniej uratowana przez polskie przedmurze Austria stała się jednym z agresorów dokonujących podziału polskich ziem (Biernat, 1989, ss. 219-220).

Założycielski potencjał mitu Antemurale Christianitatis ujawnił się w pełni dopiero wskutek rozpadu państwa. Wydawać by się mogło, iż utrata podmiotowości powinna była stanowczo wyeliminować mityczne przedmurze ze świadomości Polaków. Tak się jednak nie stało. Jedna ze szczególnych cech mitów polega na ich umiejętnościach adaptacyjnych. W treści mitu przedmurza osłabieniu uległ komponent religijny. Obronę katolicyzmu zastąpiła kwestia ochrony jakości cywilizacji. Uaktualnioną zasadę mitu, która nie tylko przetrwała, ale wręcz została wzmocniona, wyrażała dychotomia: człowiek cywilizowany - barbarzyńca. W rozumieniu XVIII i początku XIX wieku człowiek cywilizowany miał być upostaciowieniem ogłady, wyższego poziomu osiągnięć materialnych, obyczajności, a nieco później, istotą stojącą na najwyższym szczeblu rozwoju ludzkości. Przeciwieństwem tego był barbarzyńca. Istota ludzka, ale dzika, agresywna, nieprzewidywalna, niebezpieczna i warta jedynie pogardy (Kieniewicz, 2003, ss. 29-35). Cywilizowanym staje się więc Polak - obrońca zachodnich wartości, a szczególnie dorobku niedawnej rewolucji francuskiej. Esencję barbarzyństwa wyraża natomiast absolutyzm rosyjski, tak dobrze znany uciskanemu polskiemu narodowi. Nowa wersja mitu stawała się tym bardziej użyteczna politycznie, gdyż zniknął z niej komponent (nieistniejącego) państwa polskiego, a w jego miejsce pojawił się naród. Naród bez państwa może istnieć, państwo bez narodu - nie. Mimo tego, że Rzeczpospolita nie istniała, nie sposób było odmówić istnienia w tym czasie narodu, który sukcesywnie o sobie przypominał (chociażby powstańczymi zrywami). Założycielska funkcja mitu przedmurza powróci raz jeszcze z chwilą narodzin II Rzeczypospolitej jako tama przed zalewem czerwonej bolszewickiej rewolucji. 
U progu narodzin II Rzeczypospolitej struktura społeczna narodu polskiego uległa znacznym przeobrażeniom. Część szlachty przeistoczyła się w ziemiaństwo lub rozwijała karierę w aparacie administracyjnym państw zaborczych ${ }^{2}$. W znacznym stopniu doszło do jej deklasacji, szczególnie szlachty drobnej. Zmiany sprzyjały wykształceniu się nowej, świadomej narodowo warstwy - inteligencji (Schramm, 2009, s. 108). W znakomitej większości polska inteligencja przyjęła na siebie rolę "narodu politycznego" ${ }^{3}$. Mimo skromnych możliwości warstwy wykształcone podjęły trud utrzymania tożsamości narodowej. W zaborze rosyjskim i pruskim walka o ducha narodowego trwała na polu kultury oraz w myśl „pracy pozytywnej", jako alternatywy dla zrywów powstańczych, uważanych przez pozytywistów za niepotrzebne i w gruncie rzeczy szkodliwe. Wiele urzędniczych etatów w zaborze rosyjskim pozostawało w tym czasie niedostępnych dla wykształconych Polaków, co tworzyło „inteligentny proletariat” zbuntowanych mas (Wapiński, 1991, ss. 95-97). Z kolei w Galicji inteligencja wiązała się ze służbą państwową (administracją i szkolnictwem), gdzie jej aktywność kulturalna była znacznie mniej widoczna (Schramm, 2009, s. 109). $\mathrm{Na}$ gruncie skomplikowanej sytuacji społecznej funkcjonowały mity narodowe: powstańczych zrywów, mesjanizmu czy przedmurza cywilizacji. Wszystkie one wejdą do mitologii politycznej nowego państwa, chociaż żaden z nich nie odegra kluczowej roli. Warto również zaznaczyć w tym miejscu, iż mity założycielskie w dwudziestoleciu międzywojennym nie stanowiły jednej zwartej grupy. W obrębie środowisk politycznych i inteligenckich istniały najróżniejsze narracje, często wykluczające się nawzajem. Niezależnie od tego, wywalczenie niepodległości, możliwe dzięki wielu zbiegającym się w czasie wydarzeniom oraz współpracy ponad podziałami, wiązało się z jednym, aczkolwiek podstawowym problemem. Jakie wydarzenie lub osobę uznać za symboliczny początek odrodzonej Polski?

Spór o przywłaszczenie mitu założycielskiego rozegrał się w głównej mierze pomiędzy dwoma stronnictwami politycznymi: sanacją z Józefem Piłsudskim na czele z jednej strony oraz Romanem Dmowskim i środowiskiem endecji z drugiej (Kloc, 2010). Rywalizacja nie miała charakteru wyłącznie politycznego. Stworzenie mitu założycielskiego zapoczątkowywało na nowo wspólną, przerwaną zaborami historię rozdzielonego narodu. W tym sensie spór o mit założycielski był batalią o "serca i umysły" Polaków. Dodatkową motywację w uzurpowaniu sobie mitu stanowił fakt, iż obie strony w mniejszym lub większym stopniu pozostawały w przeszłości uwikłane we współpracę z zaborcami (Kloc, 2010). Ukształtowanie mitu wedle własnej wizji przesłaniało niewygodne fakty historyczne. Ostatecznie mit założycielski miał stanowić decydujący dowód na to, że droga obrana ku wolności przez jedną z sił politycznych była jedyną słuszną. Rywalizacja tocząca się w ławach sejmowych, na łamach prasy oraz w trakcie wieców politycznych zakończyła się zwycięstwem zwolenników Józefa Piłsudskiego.

Po zamachu stanu w 1926 roku obóz sanacyjny uzyskał pełnię władzy, ustanawiając, a później upaństwawiając mit marszałka Józefa Piłsudskiego, jako ojca założyciela niepodległego państwa. Sam Obywatel Komendant, jak go tytułowano w pierwszych latach

-

Służba w administracji lub armii zaborczej była udziałem wielu polskich szlachciców, którzy stawali przed dylematem zapewnienia sobie elementarnego bytu niezbędnego do przeżycia, a dochowaniem wierności szeroko rozumianej polskości. Ciekawie ów dylemat odrysowuje Max Cegielski w biografii poświęconej życiu wybitnego polskiego, aczkolwiek zapomnianego już dzisiaj podróżnika i jednocześnie generała armii carskiej Bronisława Grąbczewskiego w książce zatytułowanej Wielki gracz. Ze Żmudzi na dach świata (Cegielski, 2015).

3 Nie sposób nie wymienić przy tej okazji mieszczaństwa, które od XIX wieku aktywnie włączyło się w działalność narodowowyzwoleńczą. 
niepodległości, nie stronił od podkreślania własnego wkładu w czyn niepodległościowy (Waniek, 2011, s. 29). Mit ojca założyciela w swojej podstawowej formie opowiadał o kluczowej roli Marszałka w przygotowywaniu ostatecznego zrywu wolnościowego, a następnie o jego osobistym poprowadzeniu Polaków ku zwycięstwu nad trzema zaborczymi mocarstwami. Symboliczną datą narodzin państwa ustanowiono dzień 11 listopada, którego wybór nie był zresztą przypadkowy. Dla piłsudczyków symboliczną datą pozostawał 6 sierpnia 1914 roku, czyli dzień wymarszu Kompanii Kadrowej z Krakowa do Królestwa Kongresowego. Problem polegał na tym, że była to data kojarzona wyłącznie ze środowiskiem legionów, a nie ogółem społeczeństwa. Socjaliści i ludowcy za wydarzenie przełomowe uważali noc z 6 na 7 listopada - powstanie Tymczasowego Ludowego Rządu Republiki Polskiej. Narodowcy z kolei za datę najważniejszą uznawali 11 listopada 1918 roku, czyli dzień podpisania rozejmu w Compiegne kończącego I wojnę światową (Kloc, 2010). Pikanterii wyboru daty nadaje fakt, iż dokładnie tego dnia w Polsce nie doszło do żadnego ważniejszego wydarzenia, które posłużyłoby za pretekst do takiego, a nie innego wyboru dnia uczczenia wyzwolonej Polski. W tych okolicznościach wybór przez sanację 11 listopada na symboliczny, świętowany przez Polaków dzień niepodległości był wynikiem chłodnej kalkulacji politycznej. Z jednej strony odbierano symboliczną datę endecji, a z drugiej zagarniano dla obozu władzy całość tradycji i symboliki niepodległościowej.

W związku z tym, iż każdemu mitowi politycznemu towarzyszą bogate symbole i rytuały, mit ojca narodu przez lata istnienia II RP "dorobił" się ich wielu. Obraz Piłsudskiego kształtowano na modłę wojskową. Na próżno szukać fotografii lub obrazów, na których Marszałek występuje bez munduru. Szary uniform stał się niejako atrybutem na trwałe zrośniętym z przywódcą. Legenda Pierwszej Brygady, szarże kawaleryjskie, pieśni żołnierskie i patriotyczne, wojskowe defilady ulicami stolicy, doroczne obchody imienin Piłsudskiego, wiersze ku jego czci, czapka maciejówka, klacz Kasztanka, czy legendarne wręcz oddanie wojskowego otoczenia -- wszystko to tworzyło obudowę rytualno-symboliczną wokół osoby Józefa Piłsudskiego, jeszcze mocniej podkreślając jego znaczenie w przestrzeni publicznej. Apogeum popularności mitu ojca narodu przypadło trzy lata po śmierci Piłsudskiego, w 1938 roku. W dniu 7 kwietnia w życie weszła ustawa „O ochronie imienia Józefa Piłsudskiego, pierwszego marszałka Polski". Od tego momentu każdy, kto odważył się publicznie krytykować Komendanta lub uwłaczać jego dobremu imieniu, podlegał karze pozbawienia wolności do lat pięciu. Treść ustawy jasno wskazywała, iż postać Pitsudskiego zajmuje w panteonie symboli II Rzeczypospolitej miejsce szczególne: „Pamięć czynu i zasługi JÓZEFA PIŁSUDSKIEGO - Wskrzesiciela Niepodległości Ojczyzny i Wychowawcy Narodu - po wsze czasy należy do skarbnicy ducha narodowego i pozostaje pod szczególną ochroną prawa” [pisownia oryginalna] („O ochronie imienia Józefa Piłsudskiego, pierwszego marszałka Polski: Ustawa nr 219 z dnia 7 kwietnia 1938 roku Sejm", 1938). Ustawa pozwalała ścigać z mocy prawa wszystkich tych, którzy krytykowali Józefa Piłsudskiego lub umniejszali w jakiejkolwiek formie jego zasługi. "Ludyczny" wymiar kultu Piłsudskiego podtrzymywany przez sanację traktować należy w kategoriach do pewnego stopnia przemyślanej strategii. Po pierwsze, społeczeństwo polskie potrzebowało nieskomplikowanego mitu, z wyraźnie zarysowaną postacią męża opatrznościowego, z którym można się było utożsamiać. Po drugie, przerysowanie Piłsudskiego zwiększało jego „mityczność" w oczach odbiorców, a więc i zwiększało szacunek do państwa w ogóle. I po trzecie, Józef Piłsudski, ze swoją konspiracyjną, bojową przeszłością z jednej strony oraz inteligenckim pochodzeniem i działalnością z drugiej, nadawał się najlepiej na symbol odrodzonej Polski. 
Nieskomplikowana, biało-czarna fabuła mitu o ojcu założycielu i jego bohaterskiej drużynie, w której eksponowano samodzielny trud wywalczenia niepodległości, korespondował z samoświadomością pokolenia ukształtowanego przez tzw. wojny polskie (1918-1921). Sugestia, iż to w rękach Polaków, a nie Aliantów znajdował się klucz do wygrania własnej państwowości, jednoznacznie pociągała. Wizja taka spełniała dwie funkcje: podbudowywała poczucie własnej wartości i jednoczyła naród. Nie sposób jednak nie zauważyć, iż mit ten uwłaczał inteligencji odbiorców. Trudno sobie wyobrazić, żeby jeden człowiek, nawet geniusz o wyjątkowych zdolnościach, był w stanie przewidzieć wypadki wojenne i stworzyć strategię działania, która ostatecznie zakończyła się zdobyciem niepodległości. Ówczesne sztaby największych europejskich armii wraz z ludźmi najlepiej poinformowanymi nie były w stanie tego dokonać, co rzekomo powiodło się Piłsudskiemu. Tym bardziej trudno przyjąć do wiadomości, że nieliczna garstka legionowych idealistów doprowadziła do wyzwolenia Polski. Pobieżne nawet zestawienie sił armii zaborczych z paramilitarnymi oddziałami Kompanii Kadrowej musiało nasuwać oczywiste wnioski. Gdyby nie zbieg przyjaznych okoliczności (jak to często bywa w historii) oraz wydarzenia na wojennych frontach, Pierwsza Kadrowa byłaby niewiele znaczącym epizodem europejskiej historii. Mit ten nie był jednak skierowany do sceptyków, a do entuzjastów przedstawionej wizji narodzin państwa. Odwoływano się przy tym do emocji, a nie rozumu. Rolę kluczową w opowieści pełniła niezgoda na niewolę, a nie kalkulacja sił (Kawalec, 2012). Zgodnie z irracjonalnym komponentem mitów w ogóle, mit ojca narodu zasadzał się na dziejowej sprawiedliwości według której Opatrzność i Bóg musieli wynagrodzić zaznane w przeszłości krzywdy.

O ile mit ojca narodu bywał kontestowany przez część środowisk inteligenckich i politycznych, szczególnie komunistów z przyczyn ideologicznych oraz mniejszości ze względów przynależności narodowościowej, o tyle mit kontynuacji istnienia państwa polskiego był narracją niepodlegającą dyskusji. Według tego mitu II Rzeczpospolita stanowiła jeśli nie wprost spuściznę po Rzeczypospolitej Obojga Narodów, to z pewnością miała być jej kontynuatorką. Z tego punktu widzenia mit kontynuacji trudno uznać za klasyczny mit założycielski, chociaż funkcję taką pełnił z całą pewnością. Nacisk położony na ciągłość państwową Rzeczypospolitej miał nawiązywać do bogatej historii Polski i tym samym odbierać argumenty przeciwnikom nieprzychylnym polskiemu państwu. Tych z kolei nie brakowało w całej Europie, a uważali oni II RP za: „potwornego bękarta traktatu wersalskiego" (Mołotow), „przepraszam za wyrażenie, państwo” (Stalin), „farsę” (E.H. Carr), „defekt historii” (D. L. George), czy „ekonomiczną niemożliwość, której jedynym przemystem jest żydożerstwo" (J. M. Keynes) (Davies, 2002, s. 861). W takich okolicznościach kultywowano mit ciągłości Polski, według którego faktem rozstrzygającym o istnieniu państwa nie był zasięg terytorialny, czy ustrój polityczny, ale to, iż tworzył je ten sam naród połączony poczuciem wspólnej świadomości historycznej i narodowej. Pogląd taki, niezależnie od swojej dyskusyjności, społeczeństwo powszechnie akceptowało. Kwestią kluczową w tym przypadku pozostawała żywotność mitu, a nie jego historyczna autentyczność (Kawalec, 2012). Najbardziej wymowne tego świadectwo stanowity obie konstytucje II Rzeczypospolitej. Zarówno nowela marcowa, jak i kwietniowa zawierały w preambułach zapisy o trwałości Rzeczypospolitej. Pomostem łączącym dawną Polskę z odrodzoną miał być wielopokoleniowy opór przeciwko najeźdźcom. Rzeczpospolita trwała, póki walczyli jej synowie (Kawalec, 2012). Tym samym w opowieść założycielską włączono inny, równie żywotny mit -- powstań narodowych.

Treść tego mitu koncentrowała się na podkreślaniu zasług nielicznej, ale świadomej narodowo grupy powstańców. To ona miała być wyrazicielką zbiorowej woli Polaków. 
Dzięki polskim bojownikom o wolność w Europie obecna pozostawała świadomość istnienia walecznego narodu bez państwa. Tym samym zrywy powstańcze miały być głośnym wołaniem Rzeczypospolitej o należne jej miejsce na mapie kontynentu. Warto podkreślić, że od chwili narodzin II RP ocena powstań narodowych znacznie dzieliła opinię publiczną. Wśród krytyków przeważał pogląd (któremu notabene trudno odmówić słuszności), że kończące się klęskami irredenty wzmagały jedynie represje. Niezależnie od ocen, mit powstań jako element walki o niepodległość włączono w szerszą opowieść o odrodzeniu Polski.

Nie sposób nie wspomnieć również o jednym jeszcze micie, który na krótko powrócił do zbiorowej jaźni podczas wojny polsko-bolszewickiej. Mit przedmurza uaktywnił się w nowej odsłonie w czasie wojny z Rosją Radziecką. W uwspółcześnionej wersji oprócz komponentu starcia cywilizacji pojawił się motyw obrony katolicyzmu przed „czerwonym" ateizmem. Tym samym mit zyskał dodatkową wymowę. Nie chodziło już o walkę o wartości cywilizacji zachodniej, czy obronę odrodzonej ojczyzny. Batalia toczyć się miała również o fundament tożsamości narodowej, jakim przez wieki pozostawało chrześcijaństwo. W propagowanie mitu aktywnie włączył się Kościół. W dniu 6 lipca 1920 roku, w chwili największego zagrożenia, Episkopat ogłosił list, odczytywany w każdym polskim kościele. W odezwie pojawiło się stwierdzenie: „Polska jedna oparła się pokuśnym wołaniom tego wroga i jakby murem stanęła, aby mu wstępu do siebie i zachodu Europy zagrodzić [...] dlatego to wróg ów poprzysiągt jej zniszczenie i zemstę [...]. W takiej to ciężkiej chwili - nie dajmy dostępu do serc naszych żadnej małoduszności" (Pobóg-Malinowski, 1984, s. 451, cyt. za: Biernat, 1989). Mit przedmurza wzmocniła jeszcze legenda "Cudu nad Wisłą", dodając mu prawdziwości. Tym samym świat wyobrażony przerodził się w realny (Biernat, 1989, ss. 213-228). Antimurale Christianitatis w XX-wiecznej odsłonie wart jest uwagi również z tego względu, iż w tej samej postaci pojawi się jeszcze w 1939 roku jako wzmocnienie heroicznej batalii o niepodległość zakończoną zdradzieckim atakiem i IV rozbiorem Rzeczypospolitej.

\section{MITY ZALOŻYCIELSKIE PRL - MIĘDZY PRAWDĄ A PROPAGANDA}

Skomplikowany międzynarodowy układ sit, w którym „odrodzona” Polska znalazła się w obozie komunistycznym, wymusił stworzenie nowych mitów politycznych niezwiązanych z tradycją II Rzeczypospolitej. Komunistyczni włodarze kraju, zależni od moskiewskich zwierzchników, rozpoczęli długi i żmudny proces pisania historii na nowo. W wizji tej brakowało miejsca dla Armii Krajowej, marginalnego poparcia społeczeństwa dla nowej władzy, czystek dokonywanych przez Urząd Bezpieczeństwa, fałszowania wyborów oraz bezlitosnego rozprawiania się z opozycją demokratyczną. Równocześnie trwała praca nad ustanowieniem mitów założycielskich, sankcjonujących siłą narzuconą władzę. Kluczową rolę odegrał w tym procesie aparat propagandy, który nieprzerwanie do końca lat 80. XX wieku będzie wytwarzał szereg mitów politycznych.

Sięgająca po terror władza po 1948 roku stanęła przed wyzwaniem uzasadnienia swoich rządów w sferze symboliczno-ideowej (Polniak, 2011, s. 85). Naturalne pole odwoływania stanowiła doktryna komunistyczna. Na tym gruncie narodził się mit państwa idealnej proletariackiej sprawiedliwości. Podstawę mitu stanowiło założenie o końcu starego burżuazyjnego porządku, w którym szerokie masy pracujące żyły w ciągłym ucisku. 
i o narodzinach powojennego państwa sprawiedliwego, ustanowionego przez komunistów. Treść mitu upowszechniała wiarę w nadchodzący postęp we wszystkich niemal dziedzinach życia: gospodarczej, społecznej i politycznej. Efektem końcowym miało być, w pierwszym rzędzie, podźwignięcie kraju ze zniszczeń wojennych, a w dalszej perspektywie - ustanowienie sprawiedliwego dobrobytu, którego beneficjentami będą wszyscy na równi, a nie, jak miało to miejsce przed wojną, warstwy uprzywilejowane (Biernat, 1989, ss. 273-286). W micie wyraźnie zaznaczono, że państwo (władza) pozostawało narzędziem zaspokajania potrzeb obywateli i kierowało się wyłączną kategorią bezstronnej sprawiedliwości. Tak rozpowszechniany mit założycielski czynił z państwa instytucję niczym nieograniczoną, nieskrępowaną i limitowaną wyłącznie wolą rządzących -- państwa wszechmogącego.

Wykorzystany u zarania PRL motyw końca starego i początku nowego ładu politycznego, czyli de facto końca historii i narodzin nowego świata, sukcesywnie powielano przez propagandę państwową w momentach kryzysowych. W tym sensie mit założycielski powracał przez wszystkie lata istnienia Polski Ludowej. Pierwotnie zerwano z dwudziestoleciem międzywojennym i rozpoczęto budowę państwa od podstaw. Następnie Bolesław Bierut odżegnał się od Władysława Gomułki i odchylenia prawicowo-nacjonalistycznego, które zakończyło się publicznym rozliczeniem i nowym otwarciem. Czarny mit Bieruta jako tego, który zaprowadził stalinizm w Polsce, skwapliwie wykorzystała kolejna ekipa. Edward Gierek rozpowszechnił wizje Gomułki, który odwrócił się od klasy robotniczej, i ogłosit narodziny nowej socjalistycznej i sprawiedliwej Rzeczypospolitej Ludowej. Z kolei ekipa Stanisław Kania -- Wojciech Jaruzelski szerzyła wizję upadku gospodarczego, spowodowaną przez poprzednika, i wzięcia na siebie trudu ratowania państwa. I tak mit założycielski powracał w 1945, 1948, 1956, 1970, 1980 i 1981 roku (Sielski, 2013, ss. 14-31). Propagandyści komunistyczni ustanowili symboliczny początek nowego państwa - 22 lipca. Zniesiono tym samym 11 listopada, a nowa data nawiązywała do manifestu PKWN ogłoszonego w Lublinie w 1944 roku. Tym samym symbolicznie zerwano z przeszłością. Dokonano rewitalizacji historii, a powrót do tradycji II RP miał być od tego momentu niemożliwy. W Święto Odrodzenia organizowano pochody i turnieje sportowe, sklepy lepiej zaopatrywano oraz dokonywano oficjalnych otwarć: w 1973 roku uruchomiono pierwszą linię produkcyjną Fiata 126p, a rok później gdański Port Północny. Tego dnia wydawano również ważne akty prawne i prezentowano Polakom nowych bohaterów: w 1952 roku uchwalono konstytucję PRL, a w 1974 udekorowano Leonida Breżniewa Krzyżem Virtuti Militari (Pietrzak, 2016).

Mitowi początku oraz proletariackiego państwa sprawiedliwego towarzyszył szereg mitów pobocznych, które składały się na mitologię założycielską Polski Ludowej. Wszystkie one były podporządkowane „misji” legitymizacji władzy, trwającej aż do końca lat 80. I tak, zmianom politycznym propaganda państwowa przyporządkowywała różne fundacyjne mitologiczne narracje: mit powszechnego entuzjazmu w latach 1944-1949, mit „bohaterskiej industrializacji" w latach 1949-1956, mit siermiężnego socjalizmu w latach 19561970, mit budowy "nowej Polski” w latach 1970-1880, czy mit „socjalistycznej odnowy i porozumienia" w latach 1980-1989 (Sokół, 1997, ss. 158-170). Na uwage zasługuje również fakt, iż przez cały okres istnienia PRL próbowano uczynić z I sekretarzy KC PZPR herosów - ojców opatrznościowych państwa na wzór Józefa Piłsudskiego. Najbardziej mit herosa eksploatowano za czasów Bolesława Bieruta. Z rozmachem budowany kult rewolucyjnego bohatera i twórcy nowej Polski wyrażały hasła: "Nasz Pierwszy Budowniczy”, „Zwycięski Wódz Naszej Epoki”, „Budowniczy Polski Ludowej” czy „Sternik Polski 
Ludowej" (Sielski, 2013, s. 21). Problem polegał na tym, że ani Bierut, ani żaden kolejny I sekretarz nie dysponowali przekonywającą charyzmą (z wyjątkiem Edwarda Gierka). Znakomita większość społeczeństwa zdawała sobie sprawę, iż włodarze kraju byli w rzeczywistości administratorami państwa z nadania ZSRR. Nie bez znaczenia pozostawał również fakt, że "sternicy" Polski Ludowej zmieniali się stosunkowo często, a każdy kolejny "heros" obalał pomniki poprzednika.

Ostatnim wartym uwagi mitem wchodzącym w skład mitologii założycielskiej był mit wroga, wykorzystywany z sukcesem przez wszystkie lata PRL. Mit ten opierał się na cyklicznym wynajdywaniu wrogów Polski, którzy mieli działać na jej szkodę. Wrogiem mógł być każdy i ukrywać się wewnątrz społeczeństwa jako "zapluty karzeł reakcji” lub czyhać poza granicami kraju pod postacią "zachodniego imperialisty". Narracja opierała się w tym przypadku na dużo starszym i ugruntowanym w społeczeństwie micie polskiej państwowości i poczuciu patriotyzmu. Tym samym wewnętrznego wroga narodu przedstawiano zawsze jako zdrajcę lub szpiega. Zewnętrzny wróg natomiast dybał na jedność Polski Ludowej, wspierając krajowych zdrajców lub bezpośrednio działając na jej szkodę. Mit ten z łatwością włączano w szerszą narrację mityczną, a jego siła polegała na scalającym społeczeństwo poczuciu zagrożenia. Idealnym upostaciowieniem mitycznego wroga pozostają obrazy filmowe realizowane przez studio "lluzjon" w pierwszych powojennych latach. W "Roku pierwszym” część AKowców wolało przyłączyć się do zdradzieckich Narodowych Sił Zbrojnych, aniżeli poddać łaskawej państwowej amnestii. W "Milczących śladach" wzorowy funkcjonariusz UB kapitan Morwa odkrył spisek krakowskiej inteligencji wymierzony w państwowy ład. Film „Ogniomistrz Kaleń” przedstawiał z kolei wroga zewnętrznego pod postacią Ukraińców z Armii Powstańczej. Wzięty do niewoli tytułowy bohater poddawany serii tortur musiał patrzeć, jak jego kompanii ginęli pod ostrzem ukraińskiego topora. Cały morderczy rytuał nie przez przypadek nawiązywał do hitlerowskich Parteitagów (Polniak, 2011, ss. 86-88). Mityczny wróg mobilizowat tym samym do utrzymywania za wszelką cenę nowo powstałego państwa i sankcjonował jego istnienie. Wszak mnożący się przeciwnicy, niezależnie od tego, czy byli to inteligenci, AKowcy, Ukraińcy, czy Niemcy, mieli jeden tylko cel: ponowne zniszczenie Polski. Zatem należało zrobić wszystko, aby zniweczyć te plany.

\section{GRZECH ZANIECHANIA - MITY FUNDACYJNE III RZECZYPOSPOLITEJ}

Z chwilą nastania końca Polski Ludowej opozycyjne do niedawna siły polityczne wkroczyły w demokratyczną rzeczywistość z nowymi mitami początku, nowym zbawicielem oraz starym negatywnym mitem upadku (Sielski, 2013, s. 29). Wydawać by się mogło, iż była to sytuacja idealna do budowania zupełnie nowej, jednoczącej społeczeństwo mitologii założycielskiej III Rzeczypospolitej. Mity założycielskie w sytuacjach granicznych odgrywają doniosłą rolę. W tym przypadku kanalizowały społeczne niezadowolenie (gospodarcza zapaść, która była winą władz PRL) oraz mobilizowały masy do poświęceń (ofiara bolesnych przemian ustrojowych). Wiele rodzących się trudności oraz rozczarowań można było wyjaśnić, wspierając się mitologiczną narracją. Tym bardziej było to istotne, gdyż przewartościowywaniu ulegały dawne doktryny, a więc i ideały polityczne (w przypadku Polski odchodząca władza była w większości skompromitowana, czego nie można było powiedzieć o wszystkich państwach Europy Środkowo-Wschodniej) (Tanasoiu, 2005, ss. 112-128). 
Jak się jednak z czasem okazało, mity założycielskie III RP zbudowano na wątłym fundamencie, dającym o sobie znać zaskakująco szybko.

Skuteczność mitów demokratycznych jest większa aniżeli systemów konkurencyjnych, gdyż nie są w żadnym stopniu agresywne, nie mobilizują odbiorców skandalami, przemocą, epatowaniem złem. Przeistaczają się w pouczającą, patriotyczną lekcję (Churska, 2005, ss. 70-71). Być może ta ogólna charakterystyka pierwszych demokratycznych mitów założycielskich Polski spowodowała, że szybko uległy one wyczerpaniu w społecznej świadomości. Główne mity założycielskie III RP wiązały się z mitami Solidarności, Okrągłego Stołu oraz mitu o herosie Lechu Wałęsie wspartym autorytetem innego herosa, Jana Pawła II. Z tego punktu widzenia mity te wydawały się bardziej szlachetne aniżeli wszystkie poprzednie. Formujące się państwo w warstwie symbolicznej posiadało również to, czego zabrakło ówczesnej Rosji Jelcyna, czy zjednoczonym Niemcom -- dumę wynikającą z autentycznego samowyzwolenia (Krzemiński, 2009). Wszystkie niemal mity opierały się na formule walki dobra ze złem. Zło reprezentowane przez obóz władzy Polski Ludowej oraz dobro tworzone przez Solidarność, zjednoczone siły opozycji oraz Kościół katolicki. Na tej bazie ustanowiono mityczną narrację założycielską państwa.

Mit Solidarności głosił, że naród zbuntowany przeciwko uciskowi, zaborczej władzy oraz bezprawiu rządzących zjednoczył się, aby odzyskać niepodległość. Masy robotnicze połączyły siły z inteligencją i dzięki duchowi republikańskiemu udało się wywalczyć upragnioną niepodległość. W nawiązaniu do mitu Solidarności, niejako przy tej okazji, narodził się mit obalania komunizmu. Według niego, zło wcielone, jakim był PRL, reprezentowali ludzie nieokrzesani, niewykształceni, ograniczeni pod każdym względem, którzy przynieśli Polsce katastrofę, jednakże zostali w końcu odsunięci bezpowrotnie od władzy i zapomniani przez historię (Waniek, 2011, ss. 36-37). Żywotność mitu dostrzegalna jest dzisiaj w warstwie semantycznej i świadomościowej, gdzie na trwałe zakorzeniły się pejoratywne określenia „,komuch”, „postkomuna” i „komunista”. Mityczny komunista pozostawał (i w dalszym ciągu pozostaje) upostaciowieniem zła z jednej strony i kozłem ofiarnym wszelkich niepowodzeń oraz obiektem, na który zrzuca się winy, aby samemu pozostać nieskalanym (Żukowski, 2009, s. 4, cyt. za: Waniek, 2011, s. 36).

Mit herosa Lecha Wałęsy stanowił opowieść o prostym człowieku z ludu, który wziął na swoje barki trud odpowiedzialności za cały ruch Solidarności. Niepokorny młodzieniec, robotnik stoczniowy, religijny ojciec ośmiorga dzieci stał się symbolem narodu walczącego z wrogiem, ostatecznie doprowadził do wyzwolenia Polski, kładąc podwaliny pod nowe państwo. W ostatnich miesiącach, przy okazji ujawnienia przez Instytut Pamięci Narodowej materiałów wyniesionych z domu Czesława Kiszczaka, na temat TW Bolka (mającego być Lechem Wałęsą, współpracującym w latach 70. XX wieku z władzą), mit herosa Wałęsy powrócit w nowej odstonie.

Tym razem część środowisk politycznych oraz nieprzejednani wrogowie byłego prezydenta zażądali publicznego przyznania się do winy i przeproszenia Polaków. Gdyby rzekoma (gdyż w dalszym ciągu jednoznacznie niepotwierdzona przez historyków, ani samego zainteresowanego) współpraca okazała się prawdą, mit herosa paradoksalnie mógłby zyskać na wymowie i znaczeniu. Klasyczny mit tego typu przedstawiany jest jako zamykająca się w kręgu wędrówka, gdzie bohater wyrusza z bezpiecznej przystani (rodzinny dom Wałęsy w Popowie), podejmuje szereg bohaterskich czynów (stanie na czele strajków), zdarza mu się jednak zbłądzić (rzekoma współpraca z lat 70.), ale pojmując swoje błędy, powraca na ścieżkę prawości, by ostatecznie przezwyciężyć zło (obalenie Polski Ludowej) (Campbell, 2013, ss. 43-208). W takiej wersji heros ujawnia ludzkie słabości, a zatem 
staje się bliższy zwykłemu śmiertelnikowi. Trybun ludu Wałęsa, który znalazł się później w paszczy PRL-owskiego smoka, ostatecznie się wyzwolit i pokonał bestię, czym zaskarbił sobie szacunek rodaków i świata. Analiza mitów, szczególnie tych związanych z żyjącymi osobami, jest wyjątkowo trudna. Ich przeobrażająca się ciągle fabuła ewoluować może $w$ trudnych do przewidzenia kierunkach, a przez to niemożliwe jest zamknięcie ich w ostatecznych wnioskach. Nie zmienia to jednak faktu, iż mit herosa Wałęsy stanowił jeden z mitów fundacyjnych III Rzeczypospolitej, niezależnie od podejmowanych dzisiaj prób jego kontestowania.

Ostatnim ważnym mitem założycielskim nowej Polski pozostawał mit „Okrągłego Stołu". Według niego przedstawiciele opozycji oraz obozu rządowego, pomimo dzielącej ich nieufności, usiedli przy wspólnym stole do rozmów na temat pokojowego przekazania władzy opozycji. Dzięki temu nie doszło do rozlewu krwi, a Polska na drodze pokojowej rozpoczęła proces demontowania komunizmu w całym regionie. Podobnie jak każda wcześniejsza władza, przedstawiciele wolnej Polski stanęli przed dylematem wyboru daty symbolicznie ustanawiającej nowe państwo. Wyboru miano dokonać pomiędzy 11 listopada, nawiązując tym samym do tradycji ciągłości Polski właściwej, czyli sprzed okresu Polski Ludowej, lub 4 czerwca 1989 roku, czyli dnia częściowo wolnych wyborów będących wynikiem ustaleń Okrągłego Stołu, w konsekwencji których opozycja realnie przejęła władzę. Trudno nie zgodzić się z opinią, iż czyniąc 11 listopada Dniem Niepodległości, twórcy III RP zrezygnowali z celebrowania własnych dokonań oraz chwalebnych korzeni (Kalukin, 2013). Pomimo żywej tradycji II RP, nowa rzeczywistość wymagała własnych symbolicznych świadectw. Co ciekawe, listopadową datę przywróciły jeszcze władze PRL w lutym 1989 roku, odbierając nadchodzącym demokratom fragment należnej im symboliki.

Ostatecznie mity założycielskie składające się na mit niepodległościowy nie miały szansy zaistnieć szerzej w społecznej świadomości Polaków, gdyż część nowych elit politycznych, niezadowolonych z tempa i kierunku zmian, już w 1992 roku rozpoczęła negowanie III RP, czemu posłużyła tzw. „nocna zmiana” -- odwołanie rządu Jana Olszewskiego. Skoncentrowanie rządzących na celach politycznych (aneksja do Unii Europejskiej i NATO) oraz dbałość o rozwój ekonomiczny państwa szło w parze z zupełnym brakiem dbałości o warstwę symboliczno-etyczną oraz mitologiczną w III RP. Niezaprzeczalnym sukcesom państwa towarzyszył całkowity brak pomysłu na przekucie dokonań w ideologiczno-mityczną narrację. Pojawiające się afery (Rywina, hazardowa), arogancja władzy oraz niedoskonałości systemu państwa wytworzyły pustkę, w której już od połowy lat 90. dojrzewata idea IV RP.

\section{WARUNKI NARODZIN MITOLOGII POLITYCZNEJ IV RP}

Za wstęp do powstania nowej mitologii założycielskiej posłużyła dyskusja nad hasłem IV Rzeczypospolitej, rozpoczęta przez środowisko Koalicji Konserwatywnej w 1997 roku (Słoński, 2010, ss. 270-271). Nowe państwo miało stanowić ucieleśnienie silnego i jednocześnie zdecentralizowanego państwa. Apelowano o obronę praw rodziny, odrodzenie tradycji oraz odbudowanie ładu publicznego w oparciu o cnoty społeczne, "renesans polskości" i patriotyzm. Wizja IV RP miała być odpowiedzią na bolączki i niedomagania demokratycznego systemu (Lewandowski, 2009, ss. 378-382). W owym czasie padło również stwierdzenie, iż III RP była państwem przejściowym, wytworzonym jedynie na 
czas niezbędnych przemian ustrojowych. Warto o tym pamiętać, gdyż pogląd ten zostanie ponownie podjęty przez partię Prawo i Sprawiedliwość, głośno kontestującą władzę reprezentowaną przez liberalną koalicję rządzącą Platformy Obywatelskiej i Polskiego Stronnictwa Ludowego w latach 2007-2016. Co również symptomatyczne, hasło IV RP padło już w roku uchwalenia nowej konstytucji, co jasno wskazywało na stosunkowo szybkie próby podważania znaczenia III Rzeczypospolitej (również w warstwie symboliczno-rytualnej). O ile w 1997 roku jedynie rozpoczęto dyskusję o potrzebie ustanowienia nowego porządku państwowego, o tyle rok później powstał „Manifest Konserwatystów”, w którym po raz pierwszy zauważono, iż niezbędne będzie sformowanie nowego fundamentu aksjologicznego (a więc mitycznego również), na bazie którego wzniesiona zostanie IV RP (Matyja, 1996, s. 3). Idea IV Rzeczypospolitej z mniejszym bądź większym natężeniem powracała incydentalnie (ponownie w 2003 roku za sprawą Konwencji Konstytucyjnej Prawa i Sprawiedliwości) oraz przy okazji kolejnych ogólnopaństwowych wyborów. Przez dziewięć lat trwania w opozycji parlamentarnej PiS wytworzyło spójny program, który oprócz krytyki rządu opierał się na zagarnianiu dla siebie symboliki polityczno-historycznej (np. 11 listopada jako okazja do organizowania alternatywnych do rządowych obchodów Dnia Niepodległości). Tym samym rodziła się nowa mitologia założycielska IV Rzeczypospolitej.

Procesowi mitologizacji towarzyszyły istotne przewartościowania tego, co kryło się pod pojęciem państwa oraz oczekiwań społecznych względem władzy. Tempo zmian lat 90. oraz oczywiste ich koszty (wysoki poziom ryzyka i jego społecznego odczuwania), globalizacja z realnym i pozornym znoszeniem granic, potęgująca poczucie zagrożenia (szczególnie terroryzmem i napływem uchodźców), zwiększyły zapotrzebowanie na proste wyjaśnienia, jasno sformułowane rozgraniczenia na "my" i "oni” oraz pozorne recepty na choroby trawiące system III Rzeczypospolitej (Kaczmarek, 2006, ss. 192-196). Dodatkowo, rządząca przez lata koalicja PO-PSL nie dostrzegała zagrożenia wynikającego z braku autentycznego zaangażowania w kultywowanie symbolicznych dat, patriotycznych wydarzeń oraz podbudowywania władzy w wymiarze mitologiczno-symbolicznym. Rządzący niesłusznie sądzili, że wystarczą sukcesy ekonomiczne ( „zielona wyspa”), spokojne, a wręcz leniwe administrowanie państwem ("ciepła woda w kranie”) oraz poczucie przynależności do wspólnoty europejskiej, aby zapewnić sobie lata stabilnego sprawowania rządów (Głowacki, 2015). Nie bez znaczenia pozostawał też fakt, iż środowisko wieloletniego premiera Donalda Tuska wręcz ostentacyjnie odcinało się od współpracy ze środowiskami inteligenckimi i naukowymi (które z kolei mogły zapewnić aksjologiczne zakorzenienie dla ówczesnej III RP). W tak zdefiniowaną pustkę symboliczną wkroczyło środowisko narodowo-konserwatywne z Prawem i Sprawiedliwością na czele.

\section{KATASTROFA SMOLEŃSKA JAKO NOWY MIT ZAŁOŻYCIELSKI?}

Za mit założycielski, alternatywny względem III RP, posłużyła katastrofa prezydenckiego samolotu z 10 kwietnia 2010 roku. Na skutek śmierci prezydenta Lecha Kaczyńskiego opozycja zyskała symboliczne wydarzenie, które z czasem dało punkt zwrotny, swoisty koniec historii rozpoczynający narodziny nowej rzeczywistości (przynajmniej w oczach części polityków i społeczeństwa). Nie bez znaczenia pozostawał wymiar męczeński nadany z czasem ofiarom katastrofy oraz wymowa miejsca zdarzenia. Zasada mitu katastrofy smoleńskiej opierała się na przekonaniu, iż tragiczna śmierć prezydenta i osób 
mu towarzyszących nie była przypadkowa. Innymi słowy, poniesiona na służbie najwyższa ofiara zawierała w sobie głębszy sens, który należało odczytać (Solak \& Churska-Nowak, 2011, ss. 235-237). Sakralna przestrzeń miejsca potęgowała tylko szybkość, z jaką mit się rozprzestrzeniał w świadomości Polaków. Śmierć Lecha Kaczyńskiego miała domknąć koło czasu (Katyń 1940 -- Smoleńsk 2010) oraz przestrzeń (mord na wojskowej przedwojennej elicie Polski i śmierć elity IV RP). Tym samym dokonało się swoiste połączenie obu historycznych zdarzeń, czego wyrazem było określanie śmierci w katastrofie sformułowaniem „polegli” zamiast „zginęli”. Semantyczna zmiana świadczyła o sakralizacji zdarzenia i sugerowała, iż śmierć dosięgła męczenników w wyniku sprawy, za którą walczyli (chociaż trudno taką wskazać), a nie wskutek błędu pilota, wadliwego sprzętu czy nieprzestrzegania procedur bezpieczeństwa lotu.

Mit katastrofy smoleńskiej jako mit fundacyjny rozpoczął się z chwilą wskazania miejsca pochówku głowy państwa. Wzgórze wawelskie, gdzie spoczęło ciało prezydenta, samo w sobie kryje wiele symbolicznych znaczeń. Królewski Wawel to mit założycielski Polski. Symbol wielowiekowej potęgi dynastii Piastów i Jagiellonów. Krypta pod Wieżą Srebrnych Dzwonów, sarkofag pary prezydenckiej przy grobowcu Józefa Piłsudskiego w bezpośrednim otoczeniu koronowanych głów to symboliczny dowód na to, jak wielkoformatową postacią za życia miał być tragicznie zmarły prezydent (Solak \& ChurskaNowak, 2011, ss. 244-245). Miejsce pochówku przenosiło automatycznie na Lecha Kaczyńskiego część splendoru należnego tym, których pochowano w murach wawelskiej katedry, predestynując go tym samym do wąskiego grona historycznych mężów stanu, ojców opatrznościowych czy założycieli polskiej państwowości. Po pierwszych dniach żatoby, gdy podkreślano, iż rodzący się mit może posłużyć za punkt wyjścia do poprawy jakości bieżącej polityki, mit katastrofy smoleńskiej przejął w oczywisty sposób obóz Prawa i Sprawiedliwości z bratem zmarłego na czele, włączając go w tworzoną mitologię polityczną IV RP. Mit, uzupełniony rytualno-symbolicznymi elementami, stał się centralnym, najistotniejszym ogniwem narracji o nowej Polsce. Mityczna katastrofa od tego momentu stanowiła zdarzenie zerowe w budowie IV Rzeczypospolitej. Dodane do tego "miesięcznice smoleńskie" pod Pałacem Prezydenckim czy przemarsze z pochodniami Krakowskim Przedmieściem uatrakcyjniały uczestnictwo w kolektywnym przeżywaniu mitu. Z tego punktu widzenia mit Lecha Kaczyńskiego skoncentrował rozproszone i niespójne mity polityczne IV RP. Stał się jednocześnie fundacyjny i spajający.

Miejsce obok mitu zmarłego prezydenta znaleźli „żołnierze wyklęci”, z których obóz narodowo-konserwatywny od kilku lat próbuje uczynić zbiorowego bohatera IV RP (obok rzecz jasna powstańców warszawskich). Mit żołnierzy wyklętych skierowano do młodego pokolenia, tworząc z niego coś na kształt mody na konserwatywny patriotyzm ${ }^{4}$. Do realizacji tego celu skomercjalizowano powojenną historię oporu przed komunistami. Tragizm powojennej rzeczywistości zastąpiły koszulki z nadrukiem „1944-1963 WYKLĘCl żyli prawem wilka” oraz podkładka pod mysz z wymownym hasłem: "Nie trzeba być faszystą, by kochać ziemię ojczystą!" (Napiórkowski, 2016). Mitologię polityczną IV RP uzupełniła również coraz wyraźniejsza tendencja do zawłaszczania mitu Solidarności, niszczenia mitu Lecha Wałęsy oraz śmiało wygłaszane (również w ogólnopolskich mediach) teorie spiskowe, jakoby w prezydenckim samolocie doszło do eksplozji (Pasieczny, 2013).

Jednak starania Prawa i Sprawiedliwości, aby uczynić z mitu katastrofy smoleńskiej oraz mitu Lecha Kaczyńskiego centrum mitologii fundacyjnej IV Rzeczypospolitej, wydają

4 Dzień 1 marca jako święto Narodowego Dnia Pamięci Żołnierzy Wyklętych ustanowił w 2010 roku Lech Kaczyński. 
się skazane na klęskę. Niezależnie od tego, iż 10 kwietnia 2010 roku pozostanie w zbiorowej pamięci Polaków wydarzeniem najtragiczniejszym po 1989 roku, to potencjał założycielski powyższych mitów jest dość wątpliwy. Historyczne mity założycielskie pojawiały się w jednoznacznie dziejowych momentach granicznych: rozbiory Polski, I i II wojna światowa, upadek ZSRR. W zestawieniu z nimi wypadek samolotu prezydenckiego trudno uznać za rzeczywisty koniec historii i początek nowej państwowości. Wygłaszane przez środowisko konserwatywne opinie, jakoby Lech Kaczyński był jedynym i ostatnim prawdziwie niepodległym prezydentem Polski, automatycznie wyrzuciło poza nawias oddziaływania mitu wszystkich tych obywateli, którzy pojmowali populistyczny wydźwięk tych słów. Tym samym ograniczono zasięg wpływu mitu katastrofy smoleńskiej. Ostatecznie próba uczynienia z katastrofy mitu założycielskiego oraz Lecha Kaczyńskiego mitu herosa IV Rzeczypospolitej nie powiodła się również z tego względu, iż nie opierała się na zbiorowym doświadczeniu i emocjach, a stanowiła wyłącznie wyraz sakralizacji politycznej opowieści (Solak \& Churska-Nowak, 2011, s. 247). Z drugiej jednak strony pamiętać należy o nieprzewidywalnej naturze mitów politycznych, których najbardziej nawet absurdalne wersje zyskują rzesze zwolenników.

\section{ZAKOŃCZENIE}

Mity założycielskie począwszy od Rzeczypospolitej Obojga Narodów, a skończywszy na IV RP odgrywały zawsze podwójną rolę. Stanowiły źródło sankcjonowania istnienia państwa oraz zbiór "opowieści”, z którymi naród mógł się identyfikować. Jednocześnie, jak starałem się przedstawić powyżej, mity fundacyjne ulegały od zawsze wpływom politycznym. Wizja kształtowania mitów, a więc w konsekwencji i umysłów społeczeństwa, jest pokusą trudną do przezwyciężenia dla wszelkich środowisk politycznych. Założycielski potencjał mitów III Rzeczypospolitej w dzisiejszych warunkach rywalizacji politycznej wyczerpał się bezpowrotnie. O ich słabości świadczy chociażby fakt, iż formuła mitów z okresu przemian ustrojowych stanowi dla młodego pokolenia element „prehistorii" politycznej, z którą nie sposób się utożsamić. Propozycja obozu skupionego wokół idei IV RP ze względu na swój kategoryczny, zamykający możliwość szerszego uczestnictwa charakter, również. Wielu badaczy podkreśla, że mity polityczne, w tym założycielskie, stanowią zagrożenie dla demokracji, jako wyraz irracjonalnych imaginacji. Należy jednak pamiętać, że zbiorową tożsamość społeczeństwa nie kształtują fakty historyczne, czy chłodna kalkulacja interesów państwa, a zbiorowe wyobrażenia. Bez tego rozmywa się poczucie "wspólnoty wyobrażonej”, tak istotnej w dobie wyzwań stojących przed Polską i Unią Europejską. Rzecz w tym, aby nowa (odświeżona?) mitologia założycielska RP zakładała istnienie odmienności, których w świecie ponowoczesnym jest coraz więcej.

\section{BIBLIOGRAFIA}

Bartnik, C. S. (1990). Idea polskości. Lublin: Oficyna Wydawnicza Fundacji Solidarności

Regionu Środkowowschodniego.

Biernat, T. (1989). Mit polityczny. Warszawa: PWN.

Campbell, J. (2013). Bohater o tysiącu twarzy (A. Jankowski, Tłum.). Kraków: NOMOS. 
Cassirer, E. (1971). Esej o człowieku (A. Staniewska, Tłum.). Warszawa: Czytelnik.

Cegielski, M. (2015). Wielki gracz: Ze Żmudzi na dach świata. Kraków: Wydawnictwo Karakter.

Churska, K. (2005). Mity budujące treść demokracji. W P. Pawełczyk (Red.), Problemy wspótczesnej demokracji w ujęciu socjotechnicznym. Poznań: Wydawnictwo Naukowe Instytutu Nauk Politycznych i Dziennikarstwa Uniwersytetu im. Adama Mickiewicza w Poznaniu.

Davies, N. (2002). Boże igrzysko: Historia Polski (E. Tabakowska, Tłum.). Kraków: ZNAK.

Głowacki, W. (2015). Wina Tuska, czyli siedem grzechów głównych Platformy Obywatelskiej. Polska The Times. Pobrano 14 maja 2016, z http://www.polskatimes.pl/artykul/8963224, wina-tuska-czyli-siedem-grzechow-glownych-platformyobywatelskiej, 1,id,t, sa.html

Hobsbawm, E. (2010). Narody i nacjonalizm po 1780 roku (M. Starnawski \& J. Maciejczyk, Tłum.). Warszawa: Difin.

Kaczmarek, B. (2006). O paradoksalnej potrzebie silnego państwa polskiego. W M. Karwat (Red.), Paradoksy polityki. Warszawa: ELIPSA.

Kalukin, R. (2013, czerwiec 4). Bez mitów o III RP. Newsweek Polska. Pobrano 14 maja 2016, z http://polska.newsweek.pl/bez-mitow-o-iii-rp,104902,1,1.html

Kawalec, K. (2012). Mity założycielskie II RP. Ośrodek Myśli Politycznej. Pobrano 14 maja 2016, z http://www.omp.org.pl/artykul.php?artykul=338

Kieniewicz, J. (2003). Wprowadzenie do historii cywilizacji Wschodu i Zachodu. Warszawa: DIALOG.

Kloc, K. (2010). Spór o mit założycielski Drugiej Rzeczypospolitej, czyli dlaczego świętujemy 11 listopada. HISTMAG.ORG. Pobrano 2 czerwca 2017, z http://histmag.org/Spor-o -mit-zalozycielski-Drugiej-Rzeczypospolitej-czyli-dlaczego-swietujemy-11-listopada-4844

Krzemiński, A. (2009, kwiecień 29). Walka na mity. Polityka. Pobrano 2 czerwca 2017, z http://www. polityka.pl/tygodnikpolityka/kraj/289079,1, walka-na-mity.read

Lewandowski, A. (2009). Idea IV Rzeczypospolitej jako antidotum środowiska „Kwartalnika Konserwatywnego" na kryzys państwa. Dialogi Polityczne, 2009(12), 373-389. https://doi.org/10.12775/DP.2009.054

Łastawski, K. (2007). Historyczne i współczesne wartości polskiej tożsamości narodowej. Stupskie Studia Historyczne, 13, 279-307.

Matyja, R. (1996). Zimna wojna domowa? Nowe Państwo, 1996(1), 3.

Napiórkowski, K. (2016). Biznes wyklęty: Jak żołnierze niezłomni trafili na koszulki i zderzaki, a nawet doczekali się własnego czasopisma. Mitologia Współczesna. Pobrano 2 czerwca 2017, z http://mitologiawspolczesna.pl/biznes-wyklety-jak-zolnierze-niezlomni-trafili-nakoszulki-i-zderzaki-a-nawet-doczekali-sie-wlasnego-czasopisma/

O ochronie imienia Józefa Piłsudskiego, pierwszego marszałka Polski: Ustawa nr 219 z dnia 7 kwietnia 1938 roku. (1938). Internetowy System Aktów Prawnych. Pobrano 2 czerwca 2017, z http://isap.sejm.gov.pl/NolumeServlet?type=wdu\&rok=1938\&num er $=025$

Olędzki, M. (2011). Wojny Markomańskie 162 - 185 n.e. Warszawa: Bellona.

Pasieczny, P. (2013). Katastrofa smoleńska jako mit polityczny. Nowa Politologia. Pobrano14 maja 2016, z http://www.nowapolitologia.pl/politologia/marketing-polityczny/katastrofa-smolenska-jako-mit-polityczny

Pietrzak, L. (2016). Mit założycielski. Uważam Rze. Pobrano 2 czerwca 2017, z http:// www.uwazamrze.pl/artykul/1031568/mit-zalozycielski 
Polniak, Ł. (2011). Mit początku nowej państwowości jako kategoria legitymizacyjna W PRL na przykładzie wybranych filmów fabularnych. Zeszyty Naukowe WSOWL, 160(2), 84-99.

Schramm, T. (2009). Wyznaczniki polskiej tożsamości narodowej u progu odzyskania niepodległości. W T. Sikorski, H. Walczak, \& A. Wątroba (Red.), W kregu idei, polityki i wojska. Szczecin: Wydawnictwo Uniwersytetu Szczecińskiego.

Sielski, J. (2013). Dobre i złe mity przywódców Polski Ludowej. Annales Universitatis Paedagogicae Cracoviensis: Studia Politologica, 9, 14-31.

Siewierska-Chmaj, A. (2009). Mit polityczny jako fundament ideologii: Próba analizy. W Przekazy polityki. Kraków: Konsorcjum Akademickie.

Słoński, M. (2010). Między III a IV RP: Wokół koncepcji państwa. Przegląd Naukowy Disputatio, 11, 269-293.

Sokół, W. (1997). Legitymizacja systemów politycznych. Annales Universitatis Mariae Curie-Skłodowska: Sectio K Politologia, 2/3, 231-242.

Solak, M., \& Churska-Nowak, K. (2011). Mitologizacja katastrofy smoleńskiej: Między spontanicznością a polityczną kalkulacją. Athenaeum: Polskie Studia Politologiczne, 28, 232-247.

Tanasoiu, C. (2005). Post-Communist political symbolism: New myth - same old stories?: An analysis of Romanian political mythology. Romanian Journal of Political Science, 5(1), 111-128.

Waniek, D. (2011). Mity założycielskie - mity polityczne: Ich znaczenie w procesie kształtowania współczesnych podziałów społecznych. Państwo i Społeczeństwo, 11(4), 9-45.

Wapiński R. (1991). Pokolenia Drugiej Rzeczypospolitej. Wrocław: Zakład Narodowy im. Ossolińskich.

Zabłocki, S. (1975). Paradoksy sarmatyzmu. Teksty: Teoria literatury, krytyka, interpretacja, 3(21), 124-133. 